\title{
Climate Change, One Project at a Time
}

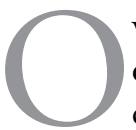

ver the past year in this country we've seen a wave of public and political reckoning with the climate change issue. Continued predicted, if unpredictable, extraordinary weather, of which Hurricane Katrina is only the most spectacular example, has helped keep this issue on the table, and political and media attention has surged. Al Gore released "An Inconvenient Truth." Polar bears have been recommended for the federal endangered species list. Despite continued intransigence at the federal level, numbers of state and local governments have adopted new policies to contend with climate change. The state of California, with the world's I3th largest economy, established its own aggressive greenhouse gas emission standards policy that helped set the stage for ten other states and over 320 city mayors across the nation to follow suit (Aulisi et al. 2007). In this issue, the new chair of SER, George Gann describes the Society for Ecological Restoration International statement on climate change issued this summer, which outlined how restoration of forests and wetlands are critical tools in carbon sequestration and climate change mitigation.

Some of this has a familiar ring, at least for those of us who have been around for a little while. Do you remember that very warm, very dry summer of 1988 when the first big wave of awareness and concern over human-induced climate change swept into the public and scientific realms? Climate change scientists James Hansen and Steven Schneider testified in front of Congress and were quoted in Time and Newsweek magazines about the climate "time bomb." They took what some observed then to be the outrageous position of activist scientist, warning us not just of warming temperatures, but of increasing variability in climate, including bigger, nastier storms. Coverage of climate change issues in newspapers, which had been relatively quiet on the topic throughout the 1980s, suddenly increased tenfold. Scientific publications like Nature and Science began to give the topic regular and central coverage (Weart 2007). The hottest summer on record in the nation's capital helped fuel a flurry of U.S. congressional activity and the World Meteorological Organization and the United Nations Environment Programme collaborated in creating the International Panel on Climate Change (IPCC), a unique hybrid of scientists and government

Ecological Restoration Vol. 25, No. 4, 2007

ISSN 1522-4740 E-ISSN 1543-4079

(O2007 by the Board of Regents of the University of Wisconsin System. officials mandated to produce final, official and agreed on information about climate change science and policy.

Almost 20 years and billions of tons of emitted carbon later, political and technological inertia has proved impressive. Yet some areas of scientific investigation and practical solution building have progressed, and the area of ecological restoration stands out. As Robert L. Peters wrote in this journal in 1985: "Efforts to improve techniques for managing communities and ecosystems under stress, and also for restoring them must be carried forward energetically. Already vitally important, it would seem these techniques will become even more so in the not too distant future," (Peters 1985, 66).

Over the past twenty years, people involved in restoration have not been waiting for a final scientific verdict on the exact causes, extent and future of ecological degradation caused by climatic change. They have worked away steadily at creating tools and developing ideas related to understanding ecosystem change and also managing that change, redirecting it toward desired states and putting pieces in place that build resilience and support ongoing stewardship. These will surely prove critical areas of expertise, for although climate change is typically discussed in global, large-scale terms, we experience it locally. Restoration both informs us about how places are responding to environmental change and also about how we might manage that change.

This issue of Ecological Restoration offers several examples of this kind of work. Tim Cater and his associates take on reproducing native plant communities on a leveled sand dune in the Arctic. Warren Devine and his colleagues report from Oregon upon research designed to control encroaching conifers in order to enhance reestablishment of Oregon white oak (Quercus garryana) communities maintained by fire in pre-disturbance times. Authors R. Michael Erwin, Jason Miller, and Jan Reese describe the U.S. Army Corps of Engineers' largest "beneficial use" dredged material project, involving rebuilding an island and creating wetland bird habitat in Chesapeake Bay using material dredged from navigation channels. While birds colonized the new island, reproduction remains a challenge for a variety of reasons including predation and habitat competition from other birds.

Roberto Lindig-Cisneros writes about his work in Mexico helping land to recover from a layer of ash deposited by a volcanic eruption in the 1940s. The blanket of ash, over two meters thick in places, has created multiple challenges 
for people working to reestablish the land as agriculturally productive. Tidal flow restoration is recognized as a key practice to repairing damage to salt marshes. As Stephen Smith reports from Cape Cod, MA, however, this involves more than just breaching the dikes, but also requires removing standing dead vegetation in order to create pathways for water flow and to allow the passage of nutrients and seeds of native species.

Much more needs to be said about climate change and restoration, of course. As James Harris and colleagues wrote recently, climate change calls into question the usefulness of historical reference systems and also requires us to rethink some basic assumptions of restoration practice, such as an exclusive reliance on local, native species (Harris et al. 2006). To consider these and other issues, we are planning a special issue of $E R$ on restoration and climate change for 2008. See the call for papers in this issue.

This issue also includes a dedication page to our associate editor Mary Ann Pels, who passed away in July. Mary Ann was central to the workings of this journal, and we miss her sorely. The good news is that assistant editor Chris Reyes has increased her hours and has proved to be a skilful editor. We have also benefited from excellent work by our temporary editor Clara Burke. We continue to be too slow in responding to manuscripts, however, and I want to thank those of you who have submitted papers and for your continued patience. I will be hiring a replacement for Mary Ann over the next few months.

I would also like to call your attention to our website (www.ecologicalrestoration.info), which offers a News page and a Gallery section. In addition, for those of you wishing to submit additional data or photographs along with your manuscripts, the University of Wisconsin Press has made it possible for us to post electronic appendices on the internet in support of articles published in Ecological Restoration.

Beginning in March of 2008, we will be introducing our "Restoration Notes" to the front of the journal. Notes have been a feature of Ecological Restoration for over 25 years, offering an effective format for sharing updates on ongoing work, experiments with new field techniques, and personal observations about restoration. For those of you who are very busy, this is an ideal format for putting your thoughts or recent research results in writing so you can share them. We look forward to hearing from you.

\section{Mrill Ingram}

\section{References}

Aulisi, A., J. Larsen, J. Pershing and P. Posner. 2007. Climate policy in the state laboratory: How states influence federal regulation and the implications for climate change policy in the United States. World Resources Institute White Paper. http://pdf.wri. org/climate_policy_in_the_state_laboratory.pdf

Harris, J.A., R.J. Hobbs, E. Higgs and J. Aronson. 2006. Ecological restoration and global climate change. Restoration Ecology 14:170-176.

Peters, R. L. 1985. Global climate change: A challenge for restoration ecology. Restoration \& Management Notes 3:62-67.

Weart, S. 2007. The discovery of global warming. American Institute of Physics Center for History of Physics. http://www.aip.org/ history/climate/

\section{A Special Issue of Ecological Restoration}

\section{CALL FOR SUBMISSIONS}

\section{What does Climate Change Mean for Ecological Restoration?}

\section{Editors, Mrill Ingram and Andrew Light}

Ecological Restoration is seeking submissions for a theme issue devoted to climate change and restoration. We welcome submissions reflecting the ecological and social implications of climate change for restoration science and practice, as well as policy, ethical and technological considerations. Article topics might include:

- What does environmental change mean for the value of reference conditions in restoration practice?

- How are restoration managers setting goals in the context of natural "moving targets"?

- How well can current federal and state land management policies that support restoration respond to climate change?

- Will climate change alter our understanding and definition of invasive species?

- If, as is frequently argued, climate change underscores the dependence of human well-being on "ecological security," how can we assure that restoration efforts are informed by the needs of more vulnerable human populations?

- Metaphors of healing abound in the restoration literature. Yet climate change involves global-scale, unpredictable and perhaps permanent ecological shifts that may not be best understood as an affliction from which we can be healed. What metaphors will prove most effective for communicating to a larger audience about the need to restore ecosystems in the context of climate change?

Deadline for submissions: June 1, 2008. Please visit www.ecologicalrestoration.info for author guidelines. Email contributions to mingram@wisc.edu and include "climate change" in subject line. 